\title{
USE OF INDEX ANALYSIS TO EVALUATE THE WATER QUALITY OF LAKES \\ NEAR WANI, DIST. YAVATMAL, INDIA
}

Shankar R. Warhate

Lokmanya Tilak Mahavidyalaya Wani, Dist. Yavatmal, Maharashatra,India Corresponding author Email : srwarhate@rediffmail.com

\begin{abstract}
:
The conventional approach of expressing different parameters of water quality in varying unit is well accepted by water resource experts. Water quality monitoring exercise was carried out with Water Quality Index (WQI) method by using water characteristics data for lakes in Wani city and around it from September.2013 to February.2014. About $80 \%$ of all the diseases of human beings are caused by water since it is directly related with human health. Therefore it is necessary to create awareness among the present and future generation about the water quality. In the present work WQI is calculated by using six water quality parameter namely hardness, alkalinity, $\mathrm{pH}$, nitrates, electrical conductivity and dissolved oxygen (DO) from four different lakes around Wani city. The sampling stations are Singada Lakes L1, Laguda lake L2, Manki lake L3 and Naigaon Lakes L4. The observed values of water quality index is in between 90.63 to 104.08 . Which indicates at station L1, and L2 the values are -Poorll and at station L3 and L4 the values are - goodll but at marginal side. However it is not suitable for drinking without proper processing.
\end{abstract}

Keywords:

Water Quality Index, Water Resources, Lakes

\section{Introduction:}

Water is a non renewable resource as we all are acquainted with the fact even than exploitation in an unsustainable manner has left this resources with deformed quality almost every where Urbanization, Industrialization, and many other anthropogenic activities as well as few natural process affects the water resources badly. Unplanned resource consumption finally put threat to the water ecosystem. Water bodies are usually taken as the dumping grounds for domestic and industrial sewage. Drinking water quality has become a critical issue in many countries especially due to concern that fresh water will be a scare resource in the future, so a water quality monitoring programme is 
necessary for the protection of fresh water resources (Pesce and Waunderlin 2000). In the last few decades there has been increasingly greater emphasis on the deterioration of Water Quality of Indian rivers (Trivedi et.al.1990, Kishor et at 1998). The water quality index (WQI) has been considered as one criteria for drinking water classification based on the use of standard parameters for water charecterization. The index is a numeric expression used to transform large quantities of water charecterization data into a single number which represents the water quality level (Sanchez et al 2007, Bordalo et al. 2006). Horton (1965) initially proposed the application of WQI and since then many different methods for the calculations of WQI have been developed by Brown R.M. at al. 1970 was based on the professional opinion of a panel of 142 water quality expert. The term water quality was developed to give an indication of how suitable the water is for human consumption (valux 2001) and is widely used in multiple scientific publication related to the necessities of sustainable management (Parparov A.et al 2006) Water quality in an aquatic ecosystem is determined by many Physical, Chemical and Biological factors( Sargaonkar et al 2003). Therefore particular problem in the care of water quality monitoring is the complexity associated with analyzing the large number of measured variables ( Boyacioglu H 2006) and high variability due to anthropogenic and natural influences (Simeonov V.2002). In the present study the sampling stations are Singada Lake L1 which is situated in the Wani City, Lalguda lakes L2 one k.m. away from Wani, Manki lakes L3 and Nigaon lakes L4 is also three k.m. away from the Wani city. Wani is located in the Maharashtra sates of India between 20 o 04' N 78 o57' E. Wani is well known as -Black Diamond cityll. Since it is surrounded from all sides by coal mines, Dolomite mines and Lime Industries. The Western coal field limited runs the underground and open cast coal mines in this area. An excessive mining and transportation of coal has badly affected the environment of the city and its surrounding area. In the present study an attempt has been made to develop Water Quality Index (WQI) using six water quality parameters hardness, alkalinity, $\mathrm{pH}$, nitrates, electrical 
conductivity and dissolved oxygen (DO) for four different lakes from September.2013 to February 2014 .

\section{Material and Method:}

The water quality parameters analysed in the present study are hardness ( $\mathrm{mg} /$. lit), Alkalinity ( $\mathrm{mg} / \mathrm{lit}$ ), $\mathrm{pH}$, nitrates ( $\mathrm{mg} /$ lit), electrical conductivity (Siemens $/ \mathrm{cm}$ ) and dissolved oxygen $(\mathrm{mg} / \mathrm{lit}$ ) according to procedure out line in Trivedi and Goel (1968) APHA (1998) and Khanna and Bhutiani (2004). Methods used for calculation of Water Quality Index includes following steps.Calculate the relative weight $(\mathrm{RW})$ by using the following equation: $\mathrm{RW}=$

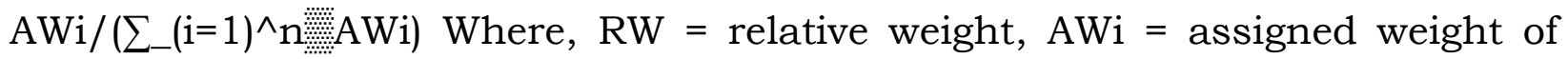
each parameter given in table $1, \mathrm{n}=$ the number of parameters. The calculated relative weight $(\mathrm{RW})$ values of each parameter are given in Calculate quality rating scale (Qi) for all the parameter (except $\mathrm{pH}$ and $\mathrm{DO}$ ) by dividing its concentration by its respective standard according to the drinking water guideline recommended which is given in Table 1 , the result was then multiplied by 100 . $\mathrm{Qi}=\mathrm{Ci} / \mathrm{Si} \times 100$ While, the quality rating for $\mathrm{pH}$ or $\mathrm{DO}$ was calculated using following, $\mathrm{Qi} \mathrm{pH}, \mathrm{DO}=(\mathrm{Ci}-\mathrm{Vi}) /(\mathrm{Si}-\mathrm{Vi}) \times 100$ where, $\mathrm{Qi}=$ quality rating, $\mathrm{Ci}=$ water quality parameter obtained from the laboratory analysis, $\mathrm{Si}=$ water quality parameter value recommended by WHO. $\mathrm{Vi}=$ ideal value which is 7.0 for $\mathrm{pH}$ and 14.6 for DO. Then calculate sub indices (SIi) for each parameter by the equation, SIi $=\mathrm{RW} \times$ Qi Finally, calculate the water quality index by taking sum of all indices. WQI $=\Sigma_{(}(\mathrm{i}=1)^{\wedge} \mathrm{n} \mathrm{n}_{\mathrm{W}}$ Sli The WQI is categorized as -Excellentll (if WQI value is less than 50); - Goodll (50-100); -Poorll(100-200); -Very poorll (200$300)$ and -Unsuitablell (>300).

\section{Result and Discussion:}

The variations in WQI in every site during the study period indicated that the water quality in L3 and L4 site is good quality and varied between 96.89 and 90.63 respectively. The variation in L1 and L2 site followed almost the same 
trend and are of -Poorll quality 101.81respectively during the study period. The WQI values of all the four stations indicate that station L1 and L2 are more polluted and station L3 and L4 are less polluted.Hardness:- The average value of total hardness of all the four stations are at higher side than the permissible limit ( $100 \mathrm{mg} / \mathrm{lit}$ ). The total hardness is an important parameter of water quality whether to be used for domestic, industrial or agricultural purposes. The increases in the hardness may due to presence of salts of calcium, magnesium and iron. Alkalinity:- The mean value of a alkalinity for all the four sites are ranged from $152 \mathrm{mg} /$ lit to $170 \mathrm{mg} /$ lit which are at higher sides from recommended values (100 mg/lit). The alkalinity in the water sample is primarily a function of carbonate, bicarbonate and hydroxide content. The higher value of alkalinity are the indicative of the eutropic nature of water $\mathrm{pH}$ :- The mean $\mathrm{pH}$ values of stations L1,L2 and L3 are in mild acidic arrange and station L4 is in mild alkaline range thus the values are within permissible limits $(6.5-8.5) \mathrm{pH}$ is an important factors that determines the suitability of water for various purposes (Ahipathy M.V. et al 2006). The observed values show a relative agreement with $\mathrm{pH}$ values of surface water which lie within the range (WHO 2004). Nitrates:-The mean value of nitrates for all the four stations are higher than the recommended values ( $50 \mathrm{mg}$./lit) during study. The possible sources of nitrate and nitrite in the surface water of all the four lakes are mainly from atmospheric surface runoff, sewage discharge, agricultural fertilizers and organic wastes. In excessive amount it contributes to the illness of infant methemoglobinemia. Electrical Conductivity :-The importance of EC is due to its measure of cations which greatly affects the taste and thus has significant impact on the user acceptance of the water as potable ( Pradeep J K 1998). It is an indirect measures of total dissolved salts. In the present study the mean value of all the four stations ranges from 230 Siemens / cm to 280 Siemens/cm at station L1 and L2 the value of EC are at higher side. Higher conductivity may arise through natural weathering of certain sedimentary rocks or may have an 
anthropogenic source industrial and sewage effluents.Dissolved Oxygen ( DO) :The dissolved oxygen shows the higher value $9.5 \mathrm{mg} / \mathrm{lit}$ at station $\mathrm{L} 1$ and lower value $8.2 \mathrm{mg} /$ lit at station L3. All the four stations have higher DO value than recommended values ( $5 \mathrm{mg} / \mathrm{lit}$ ) Khaiwal er al (2003) and Khanna et al (2007) noted the similar things in river Yamuna and in river Songs correspondingly Higher DO values indicates a possibility of organic pollution effect on water in this area.

\section{Conclusion:}

The WQI is a tool used for classification of water quality that is easy to everyone to understand and it is based on scientific criteria for water quality. The values of WQI for station L1 and L2 are 104.08 and 101.81 respectively which are categorized as -Poorll and for station L3 and L4 96.89 and 90.63 respectively and cateogorized as - goodll but at marginal level the poor WQI at L1 and L2 is due to anthropogenic activities domiestic discharge and agricultural activities. Finally it can be implied that the preventive measure taken by the local authorities are not sufficient.

\section{Acknowledgement:}

The author is thankful to Dr.S.R.Aswale, Principal, Lokmanya Tilak Mahavidyalaya, Wani for granting permission and providing necessary facilities to carry out this work.

\section{Reference:}

Khanna D.R., Bhutiani R, Tyagi B., Tyagi P. Kumar, Ruhela M. (2013) : Determination of Water Quality Index for the evaluation for surface water quality for drinking purpose. Int. Jour.of Science and Enginerring Vol.1(1) Pp 09-14.

Chaturvedi M.K., Bassin J.K.(2010) : Assesing the Water Quality Index of water treatment plant and bore wells in Delhi, India. Jour.of Environ Monit Assess vol 163 Pp 449 - 453. 
Pesce S.F,Wunderlin D.A.(2000) : Use of Water Quality indices to verify the impact of Cordoba city (Argentina) on Suguia river, Jour. of Water Research Vol.34(11) Pp 2915-2926.

Trivedi R.K, Shrotri A.C. and Khatavkar S.D.(1990) : Physico Chemcial characterstics and Phytoplankton of the river Panchganga near Kolhapur Maharashtra Rivers of India, Ashish Publication New Delhi PP 110-115.

Kishor B, Batt J, Rawat U, Nautiyal (1998), Stream Regulation Pp 87-92.

Sanchez E, Colmenarego M.F, Vicent J., Rubio A, Garcia M.G., Travieso L.(2007): Use of the Water Quality Index and dissolved oxygen deficit as simple indicators of water shed pollution, Jour. of. Ecological Indicators Vol.7 (2) Pp.315 - 328.

Bordalo A.A , Teixerra R and Wsebe W.J.(2006) : A Water Quality Index applied to an International shared river basin, Jour. of Environmental Management Vol.38, Pp 910 - 920.

Abdul Hameed M Jawad, Alobaidy Haidrs Abid, Bahram K Maulood (2010) : Application of Water Quality Index for Assessment of Dokan Lake Ecosystem, Kuridistan Region Iraq, Jour. of water resources and protection Vol.2. Pp 792-798.

Hortaon R.K. (1965): An Index number system for Rating Water Quality Jour. of Water Pollution Control Federation Vol.37 (3) Pp 300 - 306.

Brown R.M, McClelland N.I, Deininger R.A. and Tozer R.G. (1970) : A Water

Quality Index : Do we Dare ? and Water Sewage works Vol.117 (10) Pp.339 - 343.

Vaux H.J.(2001): Water Quality ( Book Review ) Environment Vol. 43 Pp - 39.

Parparov A, Hambright K.D., Hakan Son L and Ostapenia A (2006) : -Water

Quality Quantificationll Basics and Implementation, Jour. of Hydrobiologia Vol.560 (1) Pp 227-237.

Sargaonkar A, Despande V.(2003) : Development of an overall Index of Pollution for surface water based on a General Classification Scheme in Indian Context, Jour. of. Environmental Monitoring and Assessment Vol. 89 (1) Pp 43 - 67. 
Boyacioglu H (2006) : - Surface water Quality Assessment Using Factor Analysis II Water SA. Vol.32 (3) Pp 389 - 394.

Simeonov V, Einax J.W, Stanimirova I and Kraft J (2002) : -Environmentric

Modeling and Interpretation of River Water monitoring Datall, Jour. of.

Analytical and Bioanalytical Chemistry Vol.374 (5) Pp 898 - 905.

Trivedi R., Goel P.(1990) : Chemical and Biological Methods for Water Pollution studies, Karad, India.

APHA (1998) : Standard method for the examination of water and waste water ( 20th edition ) Pp $4-89$.

Bhutiani R, Khanna R. (2004) : Water analysis at a glance ASEA Publications Pp 1-115.

Ahipathy M.V. and Puttaiah E.T. (2006) : -Ecological Characteristics of Vrishabhavathy river in Banglore (India) II, Jour. of. Environmental geology Vol.49 (8) Pp.1217 - 1222.

World Health Organization (WHO) (2004) : Guidelines for drinking water quality 3 rd edition Geneva.

Pradeep J.K.(1998) : Hydrogeology and Quality of ground water around Hirapur Dist.Sagar (M.P). Jour. of pollution research Vol.17(1) Pp.91-94.

Khaiwal R, Ameena, Meenakshi, Monika, Rani and Anubhak (2003): Seasonal Variation in Physico Chemical Characteristics of River Yamuna in Haryana and its ecological best designated use, Jour. of Environment. Minit Vol.5 Pp.419-426.

Khanna D.R., Sarkar P., Gautam A and Bhutiani R.(2007): Fish scales as bio induction of water quality of River Ganga, Jour. of Environ. Monit.Asses.Vol.134. Pp 153-160. 